\title{
ISLAM AND THE FAILURE OF MODERNIZATION IN THE MIDDLE EAST
}

\author{
Ahmad Sahide \\ Gadjah Mada University
}

\begin{abstract}
This paper tries to see the encounter between Islam and modernity in the countries where the majority of the inhabitants are Muslims, particularly in the Middle East that is currently in the state of turmoil. In General, modernity failed to adapt to the Islamic states, for example the failure of democracy, which became the current joint attention in some Arab countries where the iron fist regimes are still a part of the political system. Furthermore, this paper attempts to see why modernity is difficult to adapt itself in the Middle East which began to build relations with Europe in the 18th century. Bernard Lewis, an expert who focuses on the Islamic world, argued that the failure of modernity in the Middle East and Islamic countries because of cultural factors and understanding of religion that hampered the pace of modernity. The understanding of religion is still centered on debating the democratic system and gender equality which come from the West; all of which is part of modernity. In addition, the young generations that learn a lot from the West, are not given broader space to apply their knowledge in developing and setting up a system of nationhood and statehood. These are the core issues that will be discussed further in this paper.
\end{abstract}

Keywords: Modernity, Middle East tensions, and Islam

\section{INTRODUCTION}

Speaking of the relations between the West, which is often represented by the Christians, and the East, represented by Islam seems to be interesting and important when we are entering the era of globalization. Globalization is characterized by the intense relations between communities and between countries. Bernard Lewis argues that contacts or encounters occur in three aspects: diplomacy, trade, and war. During the encounters, people always identify themselves by their origins (ancestry), religion, language, history, values, customs, and institutions.

Samuel P Huntington divides the world into two modes: us and them, the in-group and the other, our civilization and those barbarians. Muslims, traditionally also divided the world with their own term, dar al-Islam and dar al-Harb, the abode of peace and war. Edward W Said criticized the presence of the mention of us and them because $u s$, in this case the West, is always 
identified with superiority and excellence, while them, the East and the Islamic world, are seen to have a lower culture. Departing from the criticism leveled by Said above, comes the sense of curiosity about who is right and who is wrong. If Edward W Said is right with his criticism it means it is wrong to say that they are inferior. But, If Said is wrong, why is not there culture dialectics in East-West relations? The case is the East is 'influenced' by progress and the modernization of the West (Westernization). What went wrong? Why does the Islamic world adopt modernization from the West? The next question how is modernization applied in the Islamic world, especially in the Middle East?

When we glance at the history of several centuries ago, Islam enjoyed success. In the seventeenth century, the territory of the Muslims' rule expanded from Saudi to Syria, Palestine, Egypt, North Africa, and some Christian areas were occupied. Even Spain, Portugal, and France were conquered in the 18th century. At the height of its power and glory, there is no civilization that can be juxtaposed with the level of Islam, be it in terms of quality, achievement, except China. The difference is, the Chinese civilization was not global, limited only to one region, and one race group.

The Treaty of Carlowitz became a record of historical significance in the history of the Ottoman Empire, in particular, and the history of the Islamic world in General. Agreement (the Treaty) of peace was marked by the defeat of the Ottoman Empire and victory on the part of the enemy, the Christiana. This agreement provided two important lessons for the Muslims: first, in terms of the military, the defeat was due to the superior weaponry; second, more complex, defeat in diplomacy, and lessons in the negotiation process. The Treaty of Carlowitz in 1683 began when Turkey tries to beat Austria and conquer Vienna. Vienna, feeling threatened, then asked for reinforcements to the King of Poland, John Sobieski, and the request was granted by the King of Poland by sending his most powerful and organized forces. The Polish Cavalry attacked and defeated the enemy (the Ottoman Empire). The Ottoman army, which had never suffered defeat, could not do anything but had to retreat and lost 10,000 of their men and 300 units of the weapon. The Carlowitz Treaty was signed to end the war in 1699. In this agreement, Turkey was obliged to give up all the regions of Hungary, Slavonia, Croatia and to the Habsburg Transylvania and ceded Ukraine and Podolia to Poland. In the wake of this agreement, European countries started to appear and threaten the integrity of the Ottoman Empire, including Russia, which had strong ambitions to conquer Turkey.

The defeats suffered by the Muslims against Russia between the years 1768 and 1774 became the beginning of threats to the Muslims. Besides, major changes 
with rapid progress in Europe in terms of science, technology, and culture have further left the Muslims far underdeveloped. The scholars agreed to allow the two fundamental changes. First, by accepting teachers from the unbelievers to teach Muslim pupils; and second, by building alliance with the unbelievers to fight other unbelievers. New relation between the Ottoman Empire and Europe which at the same time became their enemy looks very strange. Then the start was seen quite clearly that there is something wrong. And this is realized by many of the ruling elite of the Islamic world that Europe has done the right thing, and the Muslims are getting weak and in danger.

Being aware of the reality that the triumph of Islam is now just a thing of the past, the Muslims were curious and seeking answers from questions that popped up: "what errors have we done?" and "what are the right things have they (Europeans) done?" Kocu Bey, a public servant from the Balkan, in 1630 observed that on the weakness lied on both the community service and military service of the State, so he proposed a reform to address the matter.

Unlike Kocu Bey, Lutfi Pasha, who wrote a booklet, did not focus on internal weaknesses, but on external factors instead. He argued that it is important to build strength at sea. According to him, the Ottomans secured victory on land, but the unbelievers (Europeans) were more superior at sea. And from Lutfi Pasha's point of view it posed danger to the Muslims.

Bernard Lewis did not say that the opinions of Lutfi Pasha was wrong. He argued Lutfi Pasha did not notice that the awakening of Europe was due to more concentration on domestic issues, especially in matters of administration and finance. Another important factor of rapid development in Europe was that they were open and received reports and recommendations from the people of Europe (the West) who travelled to the Islamic world. Previously, many Westerners who traveled to the Islamic World had a variety of motives and goals. Some came to carry out rituals at sacred places for Christians, some came as traders looking for profit, some came as diplomats. There were also detainees from the battlefield. Some of them were employed in the Government institutions of the Muslims. The inmates from the West who had managed to escape or redeemed and returned to the West wrote about the journey describing the results of their adventures, told about the territory and anything they saw including people they met in the world of the mysterious East.

Muslims did not do the same thing as the Westerners. Firstly because Muslims do not have sacred places to visit in Europe. European powers were also followed up with maintaining the Embassy and consultants in the Islamic world. On the contrary, Muslims did not do so. Islamic Governments only 
sent envoys to other countries when there were important things that they wanted to convey, and the Ambassador returned after conveying the important message. As for Muslims, there is a consensus that Muslims were forbidden to live in the area of the infidels. It is for the life of a good Muslim. There were fears for the Muslims of the potential conversion, from Islam to Christianity if they live in the Christian areas. This view appeared when they saw that many of the Europeans converted to Islam after making a trip to the area where the majority of the inhabitants were Muslim.

\section{A RADICAL CHANGE IN THE 18TH CENTURY}

After going through a relatively long process, which gave rise to an awareness that Europe has enjoyed a very rapid development, and the Eastern or Islamic world was increasingly left far behind, in the 18th century there was a radical change. Several ambassadors or representatives were sent to Europe instructed to observe, learn, and most importantly to report anything that might be useful for an Islamic State, such among others as how to face enemies. The ambassadors sent are as follows:

\section{Mehmet Efendi who was sent to Paris in 1721}

2. Resmi Efendi who went to Vienna in 1757, and to Berlin in 1773.

3. Vasif Efendi who was in Madrid from 1787-1789

\section{Asmi Efendi who served in Berlin in from 1790-1992}

\section{Ebu Bekir Ratib Efendi who was in Vienna from 1791-1792}

From these Ambassadors, the Islamic governments got a lot of feedback and reports. Azmi Efendi provided interesting accounts and reports on how a state is led and governed. Ebu Bekir Ratib Ali described the civil and military government systems in the Kingdom of Austria in greater detail, and especially gave recommendations on such matters which may be beneficial to emulate.

Diplomats who were sent to Europe showed their admiration to the government systems in Europe. It was Sadik Rifat Pasha who had an important role in introducing the idea and system of nation and state in Europe. He provided important notes of what he saw when he was an Ambassador in Vienna in 1837 and was amazed to see the progress and prosperity achieved by Europe. Sadik Rifat Pasha observed that wealth, industry, and science were the result of definite political conditions that ensure stability and security. This is what should be emulated by the Islamic governments, Pasha argued. Diplomatic travels to Europe were the beginning of the opening of the modernization door in the Islamic world of the Ottoman Empire. 


\section{MODERNIZATION: CONNECTING THE EAST TO THE WEST}

The rise of power and the spread of Western influence brought major changes to the three community groups in the states where the majority of the inhabitants are Muslim. Christians who benefitted economically --with the presence of the equality, and the Jews also got the benefits. The East, in response to the advancement that has been achieved by the West, emphasized more on the aspects of science. The changes brought by the West could be seen in the form of technology used both for war and for the purpose of propaganda. Other changes can be seen in terms of dress code, the public servants and bureaucracy have started wearing a suit and a tie, which is more comfortable. The military imitated the uniform from the West or Europe. Only kofiya and turban are still retained and distinguish things from the West.

In the nineteen century, the number of young Muslims, the majority of the Ottoman Empire, began to discuss how Europe, the smallest continent, could achieve a lot more things in the modern world through the mastery of science. In his essay, published in 1840, Mustafa Sami, who worked at the Embassy in Paris, gave an account of his admiration that she saw in every country in Europe where men and women could write and read. They were equal in getting access to education ten year education. Mustafa Sami also wrote his admiration in which there was a special school to teach people with visual and hearing impairment.

From the essay written by the former head of the Embassy in Paris, it was interesting to note that men and women have equal rights in education. Of course this is very much different from that in Eastern countries where women's rights are restricted to domestic duties. Women take care of the house, while men work for a living and protect their family. Domestic duties of women in Islam are maintained with the legitimacy of religion understood by Muslims.

Therefore, one of the most interesting issues as part of the modernization is the emancipation of women. In the eyes of the traditional conservatives and radical fundamentalists, the emancipation of women is Westernization and that it is not important, is useless, dangerous and against the values of Islam.

The role of women in Islamic society is viewed differently by the West regarding the role of women in socio-economic life. That men have a duty to fight while women provide pleasure to men is seen by the West as a form of injustice in which women's rights are restricted. Related to this case, Sayyed Hossein Nasar, in his book entitled "Islam, religion, history, and civilization", said that in the context of social and economic differences, the role of men and women are not in a situation to oppose each other, but rather to complement each other. He also added that the role of women is considered important, but 
not always exclusively as keeping the household and raising children, but on the other hand men are seen as protector and breadwinner of the household.

Up to now, the discourse about women and gender equality has become an inseparable part of the discussions surrounding Islam and modernity. It is the awareness raised by the issue of the democratization that has been transformed by the West in the Muslim world. As a result, we are more familiar with the idea of feminism who 'criticized' the religious teachings that put women lower than men. It was Aminah Wadud, who appeared as a controversial fighter for women's rights. According to Wadud, the teachings of the Islamic religion that are considered unfair to women are because the tafsir works were all written by men. Men and their experiences have been incorporated into the interpretations, while women and their experiences are not included, and only interpreted according to the vision, perspective, will and interests of men. The emancipation of women is still a problem by itself as a 'gift' from the modernization for the Islamic world.

The history notes that, apart from the emancipation of women, the influx of Western ideas of patriotism and nationalism has changed a lot of things and led to the creation of a number of modern nation states that extend to the Islamic world from Morocco to Indonesia. The influence of Western modernization, particularly in the system of governance, also gives rise to new problems for the Islamic world because it will give birth to new elites who will replace old elites who are not technology-wise but tend to maintain the status quo. Therefore, apart from the issue of women's emancipation brought by Western modernization, secularization in the system of a democratic government is another interesting issue. Secularism was born in the West in an attempt to resolve a long and destructive struggle over Church and State. The separation, which was adopted by America and the French Revolution and by other states, was created to prevent two things: the exploitation of religion by the State to strengthen and expand its authority and the use of power of the State by religious figures to instill or influence their doctrine.

Secularization or separation of religion and politics is not relevant to the Muslim world because Europe had a different experience with the Islamic world. From the history of the Christians, and almost in all the Christian areas, the Church and the State continue to exist side by side as different institutions, each with its own rules and its jurisdiction, hierarchy and chain of authority respectively. The highest structure of the leadership of Christianity as a religion is in the Vatican, Rome, led by the Pope. In Christianity, the Church and the State can work together in their relation, sometimes also with confrontation or conflict. Islam does not recognize this kind of leadership. Islam recognizes the 
leadership with the caliphate system, where the holder of the highest authority is God, and the Caliph is the representative of God on Earth. Therefore, in the Islamic teachings it is understood that, "Islam, the teachings, and the congregants are like the tent with its poles, ropes and pegs. The tent is Islam; the poles are its teachings (Sharia); the ropes and pegs are the congregants. They are inseparable." Therefore, it is not necessary to separate the religious institution from the State.

The correct form of human Government, according to the Qur'an, is the existence of a State acknowledgment of the leadership and power of Allah and His Messenger with regard to legislation, submitting all legislative power and the sovereignty of the Supreme law to both of them and believe that His Caliph (leader) represents the Judge, Allah Almighty.

\section{THE FAILURE OF MODERNITY IN THE MIDDLE EAST}

After we see how modernization evolves with great dynamics in the Islamic world, and also the response of many circles of the Islamic world, particularly the Middle East, the modernization in the Islamic world has suffered a great failure. Almost the entire Muslim world was hit by poverty and tyranny. We can see it in the Arab world today, from Tunisia, Egypt, to Libya, and their neighboring countries.

The combination of low productivity and a high birth rate in the Middle East made an unstable mix with a large number of unemployment and growing fast. By all indications from the United Nations (UN), the World Bank, and other countries, Arab countries - in issues like job creation, education, technology and productivity - lagged far behind the West. Even worse, the Arab countries also missed from countries that adhere to the pattern, the modernization of the West, such as Korea, Taiwan and Singapore.

The failure of modernity in the Islamic world, one of which was caused by the presence of the two challenges in the Arab world, namely the cultural and intellectual challenges. One of them is because of internal factors, which is represented by a confrontation between those who hold the doctrine of secular versus fundamentalists, with incessant questions about how to find the intersection between "political Islam" and things that are not clear (ideas from the West). Another factor is the external factor, which is represented by a historical encounter with the West and how to define the interaction of the Arab world with it. Arab social scientists in general are aware of the significant difference between "modernization" (tahdith) as a process of change that is only on skin deep, for example infrastructure development which is the sheer 
material and consumer culture, and "modernity" (hadathah) as a dynamic cultural project associated with a cultural and productive change capable of affecting the orientation of the society and individuals both intellectually and in terms of organization and civilization.

The modernization that did not work in the Islamic world, the Middle East, is caused by two factors, both external and internal. The internal factor is the emergence of different response that is properly addressed. In that respect, it is supposed to create internal dialectics for improvement and more productivity. However, this is not the case. The West cannot serve as a dialectical partner. The democratic system brought by the presence of the West is not treated as a dialectical partner to build a democratic system of Government in accordance with the values of Islam and the East as proposed by Muammar Qadafi of Libya. Building a democracy that is integrated to Islamic values is important because according to Qadafi Western capitalist democracy will only create a gap.

In my opinion, Bernard Lewis actually wanted to find out what is wrong with the modernization in the Middle East and the response to the progress of the West. Lewis showed us all that the West was once left behind by the East, but the West responded by improving science. In pursuit of advancement, the West tried to institutionalize doubt which establishes an idea to reach the level of progress. There are five stages of the birth of an idea, according to Amien Abdullah, namely: belief, habits of mind, doubt, inquiry, and all of which will finally produce meaning. Charles S Pierce distinguished between doubt and belief. The difference between people who are sure and those who are hesitant, according to Pierce, at least can be seen from two things: feeling and behavior. Those who have doubt will always feel uneasy and will strive to eliminate the doubt to find the right belief.

Lewis did not find this in the way the Islamic world responded to the progress of the West. In fact, the institutionalization of terrorism emerged from among the fundamentalist Muslims in responding to the progress of the West and the modernization in the Islamic world, the Middle East. Abdullah Saeed said that the emergence of militant Muslim extremists (fundamentalists) is caused by several factors. First, Western colonialism over the lands of Muslims. Second, the limitation and control of economic resources of Islamic countries; Islamic countries are controlled in order to remain weak; the prevention of the power of Muslims to rise up against the Western hegemony; and the occupation of Muslim lands by the West. Third, the politics of double standards applied by the West; Islamic propagation restrictions and support for the missionary circles. Fourth, the feeling of helplessness in the face of the dominant West. 
From here it can understood that fundamentalism emerged because of the deep hatred toward the West. Modernization is seen as Westernization such as the Western-style code of dress. This is a wrong perception of modernization. Then what is modernization? Modernization can be seen from various aspects, namely education, science, politics, and religion. And the modernization that is understood by the West the institutionalization of doubt. Modernization is not imitating the style and pattern of Western life.

This view seems to be in line with the modernization that is understood by Mohammed Arkoun. Arkoun said that modernization, both in the Islamic world and the Western Christian world, have two views that are interrelated: a) the old view: the ancient, traditional, classical; and b) the future view: innovation, future orientation, and decision-making by taking many things into consideration. Between the two views, there is a relationship in such a way that the changes that result in modernization is actually a potential combination of the past and the future. From traditional to modern and in the course of time from modern to traditional, and so on. Imitating the Western style and pattern is a modernization in the form of material, not intellectual or cultural modernization.

How then should the Islamic world respond to modernization and advancement of the West? Bassam Tibi observes that the Islamic world, the Middle East, in the face of Westernization took a defensive stance-culture. This culture is seen by Arnold Hottinger, a German journalist, a stance that almost all of the Islamic literature in modern times takes the form of apology and is void of creativity, a fact that cannot be attributed to the deficiencies of Muslim reasoning. Tibi warned that European culture is out to dominate the world community because it is born of the industrial revolution. The Western European culture is dominant because it has a scientific-technological basis, and Islamic backwardness because of the absence of this scientific-technological dimension. Therefore, in order to catch up with the development of the West, the Islamic world (Middle East), according to Tibi, must build the scientifictechnological culture, not defensive and anti-the-West culture. Because, in Tibi's view, the future of the Middle East cannot created by the pre-industry culture. Europe as well as the tradition of the European enlightenment and democracy cannot be condemned but it is the hegemonic powers of Europe that should be condemned since it was propagated in the past and in the present. Modernization is not purely a transformation of values. It is the industrialization and democratization of the third world, including the Middle East. 


\section{CONCLUSION}

History has recorded that Islam enjoyed times of triumph, but in the 13th century, Islam began to collapse. Europe and the West are experiencing a revival that came out as the hegemony of the world to this day. Europe and the West rose from underdevelopment because they open up to the Islamic world, have a spirit of curiosity and do not remain closed to new ideas. Learning from case of the West and Europe, we can see that the failure of modernization in the Middle East and the Islamic world is because the Islamic world is closed to the outside world (the West). There is also a strong presumption that what comes from the West is un-Islamic and modernization is nothing more than Westernization and Americanization. Modernization of the West is only captured skin deep, such as the way people get dressed, not its substance, which is institutionalization of doubt. Thus, the modernization in the Middle East has not managed to create a system of good government, failed to establish a state with good management systems in order to achieve progress.

Looking ahead, the relations between the West and Islam, especially in the countries of the Middle East, will still be filled with tension. This is because the presence of the West, in this case the United States, is seen as a symbol of the exploitation of the abundant natural resources in the territory where three great religions were born. It has been responded with a defensive culture. In the aftermath of the revolution in several Arab countries recently, the relations between the Islamic world and the West should be dialectical, and Islam should be willing to open up and learn how to build a system of good governance, effective, and efficient in serving the people. That is exactly what the West did when they realized they were left out of the Islamic world and thus they could catch up and go forward as we see it today. The underdevelopment experienced by the West and the progress of the Islamic world did not make the West close their door to the outside world or take the attitude of defensive culture.

\section{REFERENCES}

Al-Maududi, Abul A'la. Khilafah Dan Kerajaan, Evaluasi Kritis atas Sejarah Pemerintahan Islam. Bandung: Penerbit Mizan, 1996.

Choir, Tholhatul, dan Ahwan Fanani (editor). Islam Dalam Berbagai Pembacaan Kontemporer. Yogyakarta: Pustaka Pelajar, 1999.

Hendrik M., Johan (penyunting). Tradisi, Kemodernan dan Metamodernisme, Memperbincangkan Pemikiran Mohammed Arkoun. Yogyakarta: LkiS, 1996.

Hooker, Virginia and Saikal, Amin (editor). Islamic Perspectives on the New Millenium. Singapore: ISEAS, 2004. 
Lenczowski, George. Timur Tengah di Tengah Kancah Dunia. Bandung: Sinar Baru Algensindo, 1993.

Lewis, Bernard. What Went Wrong, The Clash Betwee Islam and Modernity in the Middle East. United States: Perennial, 2003. The Crisis of Islam, Islam Dalam Krisis; Antara Perang Suci dan Teror Kotor. Surabaya: Jawa Pos Press, 2004.

Mintarja, Endang, Politik Berbasis Agama, Perlawanan Muammar Qadafi Terhadap Kapitalisme. Yogyakarta: Pustaka Pelajar, 2006.

Nasr, Seyyed H., Islam, Agama, Sejarah, dan Peradaban. Surabaya: Risalah Gusti, 2003.

Said, Edward W. Orientalisme, Bandung, Penerbit Pustaka, 2001.

Tibi, Bassam. Krisis Peradaban Islam Modern, Sebuah Kultur Praindustri Dalam Era Pengetahuan Dan Teknologi. Yogyakarta: Tiara Wacana, 1994. 
